\title{
Effect of "Flora" on the Growth and Yield of Wetland Rice
}

\author{
M. A. AzIZ $^{1 *}$ \& M. A. M. MIAH ${ }^{2}$ \\ ${ }^{1}$ Department of Soil Science, Faculty of Agriculture, Sylhet Agricultural University, Sylhet-3100, \\ Bangladesh \\ ${ }^{2}$ Soil Science Division, Bangladesh Rice Research Institute, Gazipur-1701, Bangladesh
}

\begin{abstract}
One experiment was conducted at Bangladesh Rice Research Institute farm and another experiment was conducted at farmer's field, Samantopur, Gazipur during the T. aman season, 2006 in order to determine the performance of flora on the growth and yield of wetland rice. The following four treatment combinations were tested in both site: $T_{1}=$ Control (No-fertilizer), $T_{2}=$ Flora @ $3 \mathrm{ml} /$ lit. of water, $T_{3}=$ Soil Test Based (STB) dose and $T_{4}=T_{3}+$ Flora @ 3ml/lit. of water. BRRIdhan 31 was used as test crop. The blanket doses of fertilizers were applied on soil test based (STB). The experiments were laid out in Randomized Complete Block Design with 3 replications of each treatment. The sources of $N, P, K$ and $S$ were Urea, TSP, MP and gypsum. Urea was applied into three equal splits, $1 / 3$ rd basal, $1 / 3 r d$ maximum tillering stage and the remaining 1/3rd at panicle initiation stage. The treatment $T_{4}$ where chemical fertilizer was applied on STB in combination with flora produced the maximum yield but in terms of economic point of view the treatment $T_{3}$ (STB) was found superior to other treatments.
\end{abstract}

Key words: Flora, growth, yield, wetland rice.

\section{INTRODUCTION}

Flora is a plant growth regulator containing $20 \%$ Nitro Benzene. It acts as a plant energizer, flowering stimulant and yield booster. The use of plant growth regulator (PGR) in rice in Bangladesh is very little. Now the requirement is to properly understand the PGR to enhance high yield and quality. Suitable PGR are necessary for sustainable agriculture that will provide maximum rice production with good quality. The performance of this flora on the growth and yield of rice was evaluated at BRRI farm and farmer's field, Samantopur, Gazipur in transplanted aman, 2006.

\section{MATERIALS AND Methods}

Two experiments, one at Bangladesh Rice Research Institute (BRRI) farm Gazipur and the other one at farmer's field, Samantopur, Gazipur sadar were conducted during transplanted aman season, 2006. The initial soil properties of the experimental site was determined and presented in table 1. Soil texture, $\mathrm{pH}$, organic matter, available $\mathrm{P}, \mathrm{S}$ and $\mathrm{Zn}$ and exchangeable $\mathrm{K}$ were determined following standard methods (Black,1965; Jackson,1962; Walkley and Black,1935;

\footnotetext{
* Corresponding author: Assistant Professor, Department of Soil Science, Faculty of Agriculture, Sylhet Agricultural University, Sylhet-3100, Bangladesh, E-mail: azizsoil@yahoo.com

(C) 2009 School of Agriculture and Rural Development, Bangladesh Open University, All rights reserved.
} 
Olsen et al.,1954 and Page et al.,1982). The following four treatment combinations were tested in both sites: $T_{1}=$ Control (No-fertilizer), $T_{2}=$ Flora @ $3 \mathrm{ml} /$ lit. of water, $T_{3}=$ Soil Test Based (STB) fertilizer dose and $T_{4}=T_{3}+$ Flora @ 3ml/lit. of water. The experiments were laid out in a randomized complete block design with three replications having unit plot size of $5 \mathrm{~m} \times 4 \mathrm{~m}$. Fertilizer doses on STB were $93 \mathrm{~kg} \mathrm{~N}, 16 \mathrm{~kg} \mathrm{P}, 38 \mathrm{~kg} \mathrm{~K}$ and $10 \mathrm{~kg} \mathrm{~S} / \mathrm{ha}$ for BRRI farm and $73 \mathrm{~kg} \mathrm{~N}, 14 \mathrm{~kg} \mathrm{P}, 43 \mathrm{~kg} \mathrm{~K}$ and $12 \mathrm{~kg} \mathrm{~S} / \mathrm{ha}$ for Farmers' field and was applied as urea, TSP, MP and gypsum, respectively. BRRIdhan 31 was used as the test crop. Thirty-day old 2-3 seedlings/hill were transplanted with 20 $\mathrm{cm} \times 20 \mathrm{~cm}$ spacing. TSP, MP and Gypsum were applied at final land preparation. Urea was applied in three equal splits, $1 / 3$ as basal, $1 / 3$ rd at maximum tillering stage and the remaining $1 / 3 \mathrm{rd}$ at panicle initiation stage. The plant growth regulator (PGR) flora was sprayed on the rice plant at 4 different growth stages. The detail spray schedule is presented in table 2. Necessary intercultural operations were done as and when required. At maturity, the crop was harvested from $5 \mathrm{~m}^{2}$ area at the centre of each plot. The plant height, tiller and panicle production and grain and straw yield were recorded. The grain yield was adjusted to $14 \%$ moisture content. Recorded data on yield and yield components were statistically analyzed using "Analysis of Variance" technique and mean differences were adjudged with Least Significant Difference (LSD) test. Finally economic analyses were done to identify the most economically viable treatment.

Table 1. Initial Soil Characteristics of the Experimental Site of Flora, T. Aman 2006

\begin{tabular}{lll}
\hline \multirow{2}{*}{ Parameters } & \multicolumn{2}{c}{ Value } \\
\cline { 2 - 3 } & \multicolumn{1}{c}{ BRRI farm, Gazipur } & \multicolumn{1}{c}{ Farmers Field, Gazipur } \\
\hline Texture & Clay- loam & Clay- loam \\
$\mathrm{pH}(1: 2.5)$ & 6.20 & 5.42 \\
Total N (\%) & 0.08 (Very low) & 0.14 (low) \\
Available P(ppm) & 8.6 (low) & 10.19 (low) \\
Exchangeable K(meq/100g soil) & 0.14 (low) & 0.12 (low) \\
Available S (ppm) & 14 (low) & 9.5 (low) \\
Available Zn(ppm) & 2.66 (very high) & 3.03 (very high) \\
\hline
\end{tabular}

Table 2. The application time and rate of flora in rice

\begin{tabular}{lcc}
\hline Spray schedule & Spray time & Spray volume \\
\hline First spray & 7 days before transplanting & 10 lit. for the required nursery \\
Second spray & 25 days after transplanting & 100 lit./ha \\
Third spray & 50 days after transplanting & 160 lit./ha \\
Fourth spray & 75 days after transplanting & 160 lit./ha \\
\hline
\end{tabular}

\section{Results And Discussion}

\section{Growth and Yield \\ BRRI Farm, Gazipur}

Application of flora or chemical fertilizer either alone or in combination increased the plant height, tiller and panicle production and 1000-grain weight and decreased the sterility percentage of grain than that of control plot (Table 3). The highest plant height, tiller and panicle production and the lowest sterility percentage was observed in treatment $\mathrm{T}_{4}$ (STB + Flora @ 3ml/lit. of water) followed by treatment $\mathrm{T}_{3}$ (STB). Application of inorganic fertilizer or flora either alone or in combination increased the grain and straw yield of rice over control. Application of flora alone increased the grain and straw yield over control and STB fertilization further increased the yield over flora treated plot. The grain and straw yields were further increased but not significantly with the combined application of inorganic fertilization STB and flora. The results indicated that the application of flora alone significantly increased the grain yield over control but in combination with chemical fertilizer on STB did not significantly influenced the grain yield. The increased panicle production per unit 
area, increased 1000 grain weight and decreased sterility percentage with the application of flora or STB fertilization either alone or in combination may support the increased grain and straw yield.

Table 3. Effect of Flora alone and in combination with chemical fertilizer on the growth and yield of wetland rice, BRRI, Gazipur, T. Aman, 2006

\begin{tabular}{cccccccc}
\hline Treatment* & $\begin{array}{c}\text { Plant } \\
\text { height }(\mathrm{cm})\end{array}$ & $\begin{array}{c}\text { Tiller } \\
\text { No./m }\end{array}$ & $\begin{array}{c}\text { Panicle } \\
\text { No./m }\end{array}$ & \% Sterility & $\begin{array}{c}\text { 1000- grain } \\
\text { weight }(\mathrm{g})\end{array}$ & $\begin{array}{c}\text { Grain yield } \\
\text { (t/ha) }\end{array}$ & $\begin{array}{c}\text { Straw yield } \\
\text { (t/ha) }\end{array}$ \\
\hline T1 & 105 & 159 & 140 & 30 & 23.4 & 2.83 & 3.87 \\
T2 & 114 & 175 & 163 & 28 & 24.3 & 3.33 & 4.53 \\
T3 & 122 & 202 & 187 & 28 & 24.5 & 4.22 & 5.72 \\
T4 & 125 & 211 & 190 & 27 & 24.5 & 4.48 & 5.81 \\
\hline LSD (5\%) & 6.8 & 10 & 12.8 & 5 & 2 & 0.39 & 0.25 \\
\hline
\end{tabular}

\section{Farmer's Field, Samantopur, Gazipur}

Application of flora or chemical fertilizer on STB alone or in combination increased the plant height, tiller and panicle number of rice over control. The highest plant height and maximum number of tillers and panicles were recorded in treatment $\mathrm{T}_{4}$ (STB + Flora @ 3ml/lit. of water) followed by treatment $\mathrm{T}_{3}$ (STB) (Table 4). On the other hand, application of Flora alone or chemical fertilizer on STB alone or in combination with flora increased the grain and straw yields of rice over control. The treatment $\mathrm{T}_{4}$ produced the maximum grain and straw yields followed by the treatment $\mathrm{T}_{3}$. From the results it appears that alike BRRI farm, Gazipur the application of flora alone statistically increased the grain yield over control but in combination with chemical fertilizer did not significantly increased the grain yield over STB.

Table 4. Effect of Flora alone and in combination with chemical fertilizer on the growth and yield of wetland rice, Samantopur, Gazipur, T. Aman, 2006

\begin{tabular}{cccccccc}
\hline Treatment* & $\begin{array}{c}\text { Plant } \\
\text { height }(\mathrm{cm})\end{array}$ & $\begin{array}{c}\text { Tiller } \\
\text { No./m }\end{array}$ & $\begin{array}{c}\text { Panicle } \\
\text { No./m }\end{array}$ & \%Sterility & $\begin{array}{c}\text { 1000- grain } \\
\text { weight }(\mathrm{g})\end{array}$ & $\begin{array}{c}\text { Grain yield } \\
(\mathrm{t} / \mathrm{ha}\end{array}$ & $\begin{array}{c}\text { Straw yield } \\
(\mathrm{t} / \mathrm{ha})\end{array}$ \\
\hline T1 & 120 & 230 & 215 & 31 & 24.4 & 2.67 & 3.75 \\
T2 & 121 & 251 & 242 & 27 & 24.3 & 3.22 & 4.47 \\
T3 & 124 & 278 & 263 & 29 & 24.1 & 4.24 & 5.46 \\
T4 & 125 & 283 & 272 & 26 & 24.5 & 4.50 & 5.62 \\
LSD (5\%) & 0.99 & 16 & 12 & 2 & 2 & 0.32 & 0.58 \\
\hline
\end{tabular}

${ }^{*} \mathrm{~T}_{1}=$ Control (No-fertilizer), $\mathrm{T}_{2}=$ Flora @ 3ml/lit. of water, $\mathrm{T}_{3}=\mathrm{STB}$ and $\mathrm{T}_{4}=\mathrm{T}_{3}+$ Flora @ 3ml/lit. of water

\section{Economic analysis}

\section{Net benefit}

Economic analysis on partial budget of the experiment is presented in Table 5 and 6 . The net benefit of each treatment is calculated by subtracting the total costs that vary from the gross field benefit. The total costs that vary are the sum of all the costs that vary for a particular treatment. The maximum net benefit was achieved in treatment $T_{4}$ followed by $T_{3}$ in both the experimental sites.

\section{Dominance and marginal analysis}

The analysis has been done in stepwise manner, passing from the treatment with the lowest costs that vary to the next considering. As the increase in cost, the net benefit would be increased.

It is well known that the minimum marginal rate of return for the crop is $100 \%$. If the marginal rate of return of the change from the first to the second treatment is equal or above the minimum marginal rate of return then the next comparison has been made between second and third treatment (not between first and third). This comparison has been continued (i.e. increasing level of investment) until the marginal rate of return falls below the minimum rate of return. 
Table 5. Economic analysis of "Flora" in wetland rice BRRI, Gazipur, T. Aman, 2006 a) Total variable cost (TVC) in Tk./ha

\begin{tabular}{cccccc}
\hline Treatment & $\begin{array}{c}\text { Fertilizer } \\
\text { cost }^{*}\end{array}$ & $\begin{array}{c}\text { Fertilizer } \\
\text { application cost }\end{array}$ & $\begin{array}{c}\text { Flora } \\
\text { spraying cost }\end{array}$ & $\begin{array}{c}\text { Labor cost for } \\
\text { additional product }\end{array}$ & TVC \\
\hline T1 & 0 & 0 & 0 & 0 & 0 \\
T2 & 387 & 0 & 560 & 140 & 1087 \\
T3 & 4010 & 280 & 0 & 389 & 4679 \\
T4 & 4397 & 280 & 560 & 462 & 5699 \\
\hline
\end{tabular}

* Total fertilizer cost included chemical fertilizer and flora.

Urea $=$ Tk. $6.00 / \mathrm{kg}, \mathrm{TSP}=\mathrm{Tk} 18.00 / \mathrm{kg}, \mathrm{MP}=\mathrm{Tk} .14 .00 . / \mathrm{kg}$, Gypsum= Tk. 5.00/kg, Flora= Tk. $300 /$ lit.

Labor wage $=$ Tk.140/day, Two additional man days/ha are required for applying fertilizer, two man days/ha for per ton additional products including byproducts and four man days/ha for spraying flora.

\section{b) Net benefit in Tk./ha}

\begin{tabular}{lcccc}
\hline Particulars & \multicolumn{4}{c}{ Treatments } \\
\cline { 2 - 5 } & $\mathrm{T}_{1}$ & $\mathrm{~T}_{2}$ & $\mathrm{~T}_{3}$ & $\mathrm{~T}_{4}$ \\
\hline Grain yield (t/ha) & 2.83 & 3.33 & 4.22 & 4.48 \\
Straw yield (t/ha) & 3.87 & 4.53 & 5.72 & 5.81 \\
Gross field benefit, grain (Tk/ha) & 28300 & 33300 & 42200 & 44800 \\
Gross field benefit, straw (Tk/ha) & 7740 & 9060 & 11440 & 11620 \\
Total gross field benefit (Tk/ha) & 36040 & 42360 & 53640 & 56420 \\
Total gross field cost (Tk/ha) & 0 & 1087 & 4679 & 5699 \\
Net benefit (Tk/ha) & 36040 & 41273 & 48961 & 50721 \\
\hline
\end{tabular}

Paddy $=$ Tk.10.00/kg and straw $=$ Tk. $2.00 / \mathrm{kg}$

Table 6. Economic analysis of "Flora" in wetland rice at farmer's field Samantopur, Gazipur, T. Aman, 2006

a) Total variable cost (TVC) in Tk./ha

\begin{tabular}{cccccc}
\hline Treatment & $\begin{array}{c}\text { Fertilizer } \\
\text { cost }^{*}\end{array}$ & $\begin{array}{c}\text { Fertilizer } \\
\text { application cost }\end{array}$ & $\begin{array}{c}\text { Flora } \\
\text { spraying cost }\end{array}$ & $\begin{array}{c}\text { Labor cost for } \\
\text { additional product }\end{array}$ & TVC \\
\hline T1 & 0 & 0 & 0 & 0 & 0 \\
T2 & 387 & 0 & 560 & 154 & 1101 \\
T3 & 3761 & 280 & 0 & 440 & 4481 \\
T4 & 4148 & 280 & 560 & 512 & 5500 \\
\hline
\end{tabular}

*Total fertilizer cost included chemical fertilizer and flora.

Urea $=$ Tk. $6.00 / \mathrm{kg}, \mathrm{TSP}=\mathrm{Tk} 18.00 / \mathrm{kg}, \mathrm{MP}=\mathrm{Tk} .14 .00 . / \mathrm{kg}$, Gypsum= Tk. 5.00/kg, Flora= Tk. $300 / \mathrm{lit}$

Labor wage= Tk.140/day, Two additional man days/ha are required for applying fertilizer, two man days/ha for

per ton additional products including byproducts and four man days/ha for spraying flora.

\section{b) Net benefit in Tk./ha}

\begin{tabular}{lcccc}
\hline Particulars & \multicolumn{4}{c}{ Treatments } \\
\cline { 2 - 5 } & $\mathrm{T}_{1}$ & $\mathrm{~T}_{2}$ & $\mathrm{~T}_{3}$ & $\mathrm{~T}_{4}$ \\
\hline Grain yield (t/ha) & 2.67 & 3.22 & 4.24 & 4.5 \\
Straw yield (t/ha) & 3.75 & 4.47 & 5.46 & 5.62 \\
Gross field benefit, grain (Tk/ha) & 26700 & 32200 & 42400 & 45000 \\
Gross field benefit, straw (Tk/ha) & 7500 & 8940 & 10920 & 11240 \\
Total gross field benefit (Tk/ha) & 34200 & 41140 & 53320 & 56240 \\
Total gross field cost (Tk/ha) & 0 & 1101 & 4481 & 5500 \\
Net benefit (Tk/ha) & 34200 & 40039 & 48839 & 50740 \\
\hline
\end{tabular}

Paddy $=$ Tk.10.00/kg and straw $=$ Tk. $2.00 / \mathrm{kg}$ 
The maximum marginal rate of return was obtained with treatment $T_{3}$ (both sites). Farmers will continue to invest as long as the returns to each extra unit invested (measured by MRR) which are higher than the cost of the extra invested (measured by the minimum acceptable rate of return) (Table 7 and 8 ). Thus it can be concluded that $T_{3}$ (both sites) is the most economically viable treatment of the experiment.

Table 7. Dominance and marginal analysis of "Flora" for rice production, BRRI, Gazipur, T. aman 2006

\begin{tabular}{cccc}
\hline Treatments $^{*}$ & Total costs that vary (Tk./ha) & Net benefit (Tk./ha) & Marginal rate of return (\%) \\
\hline T1 & 0 & 36040 & \\
T2 & 1087 & 41273 & \\
T3 & 4679 & 48961 & 214 \\
T4 & 5699 & 50721 & 173 \\
\hline
\end{tabular}

Table 8. Dominance and marginal analysis of "Flora" for rice production, at farmer's field Samatopur, Gazipur, T. aman 2006

\begin{tabular}{cccc}
\hline Treatments & Total costs that vary (Tk./ha) & Net benefit (Tk./ha) & Marginal rate of return (\%) \\
\hline T1 & 0 & 34200 & \\
T2 & 1101 & 40039 & \\
T3 & 4481 & 48839 & 260 \\
T4 & 5500 & 50740 & 187 \\
\hline
\end{tabular}

* $\mathrm{T}_{1}=$ Control (No-fertilizer), $\mathrm{T}_{2}=$ Flora @ 3ml/lit. of water, $\mathrm{T}_{3}=\mathrm{STB}$ and $\mathrm{T}_{4}=\mathrm{T}_{3}+$ Flora @ 3ml/lit. of water

\section{Conclusions}

The treatment $\mathrm{T}_{4}$ where chemical fertilizer was applied on STB in combination with flora produced the maximum yield but in terms of economic point of view the treatment $T_{3}$ (STB) was found superior.

\section{Literature Cited}

Black, C.A. Methods of soil analysis. 1965. Part I and II. Amer. Soc. Agron. Inc. Pub., Madison. USA.

Jackson, M.L.1962. Soil Chemical Analysis. Constable and Co. Ltd. London.

Olsen, S.R., C.V. Cole, F.S. Watanable and L.A. Dean, 1954. Estimation of available phosphorus in soils by extraction with Sodium carbonate. U.S. Dept. Agr. (Circ.) p 929.

Page, A.L., R.H. Miller and D.R. Keeney, 1982. Methods of Soil Analysis Part 2. $2^{\text {nd }}$ Ed. Am. Soc. Agron. Increased. Madison. Wisconsin, USA.

Walkley, A. and A.I. Black, 1935. An examination of the Degtijaref method for determining soil organic matter and a proposed modification of the chromic acid titration method. Soil Sci., 37, 29-38. 